\title{
AGRICULTURAL ASSETS' INFLUENCE ON BUILDING FARMERS' RESILIENCE IN ROMANIA. FOOD SECURITY APPROACHES
}

Raluca Andreea-Ion ${ }^{1}$, Cristian George-Popescu², Marinela Ilie ${ }^{3}$, Daniela Popa ${ }^{4}$

*Corresponding author E-mail: popadaniela256@gmail.com

\begin{abstract}
A R T I C LE I N F O
A B S T R A C T

Original Article

Received: 03 January 2021

Accepted: 19 January 2021

doi:10.5937/ekoPolj2101101A

UDC 338.043:355.225(498)

Keywords:

resilience, agricultural assets, land, machineries, livestock, food supply

JEL: Q10, Q14, Q20

An increasing number of scientific papers has been written on the topic of resilience. It explains the way individuals and regions face to shocks and stressors. It focuses on farmers' resilience and food security. The main shocks related to food insecurity are weather variability, volatility, and agricultural assets. We assume that the level of assets plays a role in assessing the risk level of individuals' exposure to shocks and stressors. The case of Romania is discussed, using statistical data concerning land, machineries and livestock, as main agricultural assets. The data have been analyzed using simple regression model. The results show medium influences of the agricultural assets on food supply. Significant influences have registered in macro region four: West and South-West, for land, machineries and swine. The results can be used in political frameworks and strategies and to widening the knowledge in the field of farmers' resilience.
\end{abstract}

(C) 2021. EA. All rights reserved

\section{Introduction}

Resilience is a modern concept which helps understanding the way individuals, households, and regions face to shocks and stressors, and an increasing number of

1 Raluca Andreea Ion, Ph.D., Professor, Department of Agro-food and Environmental Economics, The Bucharest University of Economic Studies, Romania-Bucharest, Phone: 00407229593 53, E-mail: raluca.ion@eam.ase.ro, ORCID ID (https://orcid.org/0000-00017182-5809)

2 Cristian George-Popescu, Ph.D., Associate Professor, Department of Economical and Administrative Sciences, The University of Bucharest, Phone: 00407582491 77, E-mail: cristian.popescu@faa.unibuc.ro, ORCID ID (https://orcid.org/0000-0002-1995-1469)

3 Marinela Ilie, Ph.D., student, The Bucharest University of Economic Studies, RomaniaBucharest, Phone: 00407480707 68, E-mail: marinela.ilie93@gmail.com, ORCID ID (https://orcid.org/0000-0002-7534-2852)

4 Daniela Popa, Ph.D., student, The Bucharest University of Economic Studies, RomaniaBucharest, Phone: 00407225630 85, E-mail: popadaniela256@gmail.com, ORCID ID (https://orcid.org/0000-0002-7492-7744)

http://ea.bg.ac.rs 
academic papers and reports has been written on the topic. It is issued from system theory as "the ability of a system to bounce back or return to equilibrium following disturbance" (Holling, 1973). The concept then developed to a complex approach. As regards the food system resilience, it could be considered resilient in the situation in which it can maintain production of enough and nutritious food in the face of both chronic and acute social, economic and environmental perturbations.

The environment is continuously changing. Nowadays, the internal and external business environments are changing more rapidly than ever before (Stankevičiūtè, $\&$ Wereda, 2020). When speaking about dynamics and disturbance at the farm level, farmers have been always living and working in changeable environments, where socio-economic, ecological, and political risks are there. As other authors observed, (Berkes and Turner, 2006; Gunderson and Holling, 2002), major economic and social changes alter the farmer-environment relationship, and a new balance develops.

At the microeconomic level, the authors Milestad and Darnhofer (2003) developed a system of criteria for assessing farm resilience. It is based on farming systems literature, mentioned by Röling and Jiggins (1998), Pretty (1998), (2002), and Ellis (2000). Agrofood systems have been analyzed from a variety of angles and with various purposes. One direction of research concerns the knowledge of farmers and their strategies to cope with and adapt to change (Scoones and Thompson, 1994; Sumberg and Okali, 1997; Ellis, 2000; Hoffmann et al., 2007; Burešova et al., 2020; Jokić, 2020).

Milestad (et al. 2009) explored how farmers' experiments can contribute to developing socio-economic and ecological resilience on farms and in the regional food systems.

The resilience could be measures using different methods. One of them is the "Resilience Index Measurement and Analysis" (RIMA), developed by FAO (2016). It consists in assessing the following indicators comprised into four pillars: access to Basic Services, which shows the possibility of a household to meet their members' basic needs, as follows: sending children to school; accessing water supplies, electricity and sanitation facilities; assets, which allow households to produce and consume goods and services; social safety nets that assess the possibility of the household to have access to formal and informal assistance from public and private institutions, likewise from their relatives and friends; and adaptive capacity which consists in the possibility to adapt to new situations and develop new livelihood strategies.

This paper aims to assess the influence of agricultural assets' on building farmers' resilience. Productive and non-productive assets are the key elements of a household, since they allow them to produce and consume goods. The indicators used are agricultural asset, land for cropping, livestock, house value etc.

The hypothesis tested in this piece of research argues that the level of assets plays a role in assessing the risk level of farm's exposure to shocks and stressors and cause the level of food supply of a household. 
This paper analysis the economic resilience in relation to food security. Following the introduction, the paper is divided into three main parts, followed by conclusions. Part 2 presents an overview of the regions of development in Romania. The data and methods of determining the resilience are presented in part 3. Part 4 presents the results of the regression models. Finally, part 5 draws the conclusions, and validates the hypotheses.

\section{Overview of the development regions of Romania}

Resilience explains how individuals and/or regions face to shocks and stressors. This paper investigates the regional resilience, thus an overview of the development regions in Romania is presented.

Regional policy is one of the key issue of the European Union. It is addressed to all the EU regions, both rural and urban, and it aims to boost economic growth and employment, in order to finally improve the quality of life through strategic financial investments (European Commission, 2020). Regional development focuses on creating and diversifying the economic activities, by stimulating investments meant to reduce the socio-economic differences between various regions (Apostolache, 2014).

A region is defined in EU's documents as "the next level after the state" or "a territory that forms a net unit from geographical point of view. It also means a similar assembly of territories having continuity, and population sharing certain common elements and willing to keep and develop their specificity for stimulating the cultural, social and economic progress" (European Commission).

From statistical point of view and data collection reasons, at the EU level there were created territorial units called NUTS (Nomenclature of Territorial Units for Statistics). They are organized on six territorial levels that depend on the number of inhabitants and the level of development. The European Union regional development policy envisages NUTS II level. At this level, the average size of the regions is 2.5 million people, and 13.000 sq. km (Apostolache, 2014).

According to Law no.315 (2004) on regional development, in Romania there are set up eight development regions, comprised into four main macro regions. The macro region one comprises North-West and Center Regions. The macro region two comprises the North East and South East Regions. The macro region three comprises South-Muntenia and Bucharest-Ilfov Regions. The macro region four comprises the South-West Oltenia and West Regions. They belong to NUTS II level and they are subject of the regional development policy, which is considered a key factor that facilitates the absorption of EU funds, through Rural Development National Program (Istudor, 2006).

The regions vary in size, assets and development. Considering the GDP as the main indicator showing the development of a region, in Table 1 and Figure 1, the GDP values per capita are presented, for the period 2012-2018. It can be noticed that the highest values registered in the region Bucharest, the GPD reached a pick of 22,803 euro/ 
person, in 2018. It is followed by the region West, which registered a value of 10,287 euro/person, in 2018. Still, the values of GDP in all regions are half of its value in the region Bucharest.

Table 1. GDP per capita by region of development, in Romania, 2000-2018 (euro/inhabitant)

\begin{tabular}{|l|r|r|r|r|r|r|r|}
\hline Development region & \multicolumn{1}{|c|}{2012} & \multicolumn{1}{l}{2013} & 2014 & \multicolumn{1}{l|}{2015} & 2016 & 2017 & 2018 \\
\hline North-West & 5302 & 5638 & 6083 & 6475 & 7153 & 8385 & 9201 \\
\hline Center & 5849 & 6108 & 6415 & 6871 & 7571 & 8540 & 9572 \\
\hline North-East & 3819 & 4085 & 4250 & 4497 & 4861 & 5640 & 6311 \\
\hline South-East & 5213 & 5844 & 6211 & 6303 & 6659 & 7404 & 8322 \\
\hline Bucharest & 14141 & 15296 & 15935 & 17673 & 18596 & 20817 & 22803 \\
\hline South-Muntenia & 4644 & 5132 & 5832 & 5838 & 6362 & 6935 & 7806 \\
\hline South-West Oltenia & 4607 & 4823 & 4942 & 5342 & 5719 & 6685 & 7755 \\
\hline West & 6436 & 6791 & 6972 & 7659 & 8445 & 9277 & 10287 \\
\hline
\end{tabular}

Source: National Institute of Statistic of Romania

A general increasing trend of the values of GDP can be observed in Figure 1, for all regions, over the period under analysis. The GDP grew up to 60-70\% in 2018 as compared to 2012, depending on the region. The highest growth registered in the region North West, considered to be the most dynamic region in Romania.

Figure 1. GDP per capita by region of development, in Romania, in the period 2012-2018 (euro/inhabitant)

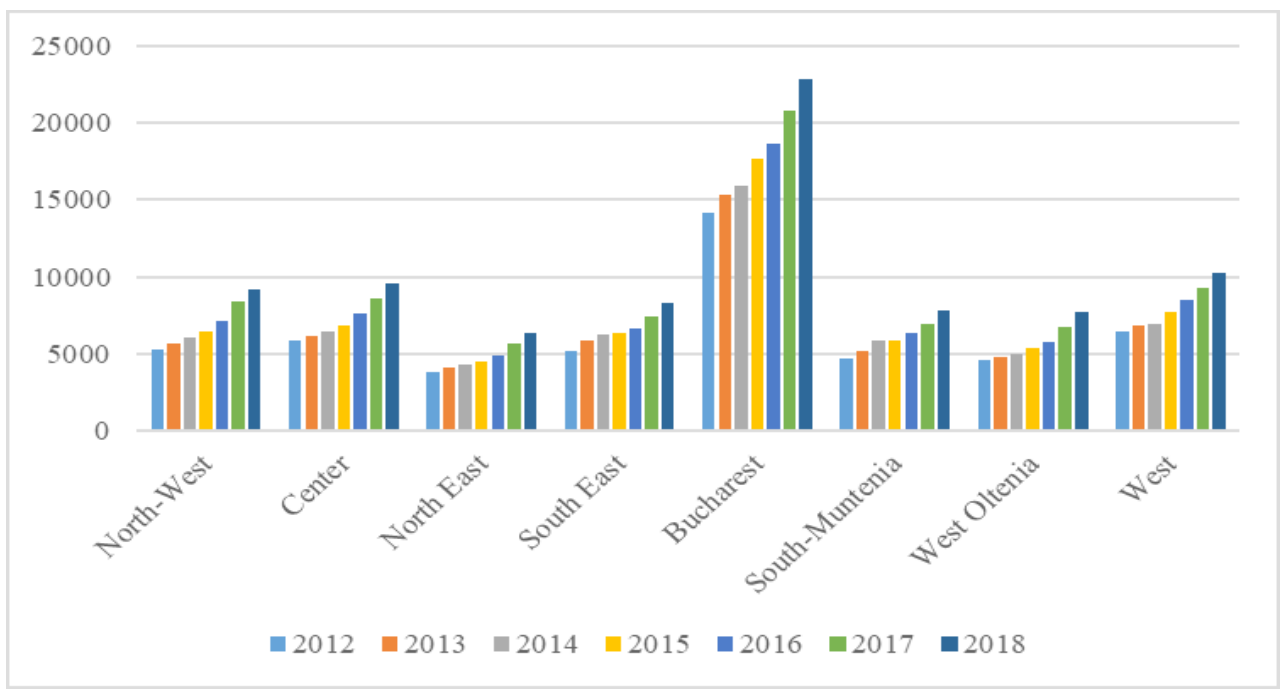

Source: National Institute of Statistic of Romania 


\section{Materials and methods}

It is assumed that the regions with high levels of GDP are able to ensure food security for its inhabitants. In this paper, the relationships between assets, particularly agricultural assets, and food security are analyzed.

The influence of agricultural assets on farmers' resilience can be explained by the relationship between the endogen variable, food security, and the exogenous variable, resilience capacity, with its shocks and stressors. Within this paper, the exogenous variable is agricultural assets, as pillar of resilience, and the endogen variable is food security, considered as an effect or outcome of individual's well-being.

The indicators suitable to agricultural assets are land for cropping, technical endowments and livestock. They are presented in Figure 2. The indicator suitable to food security is food supply rendered in daily calories consumed per person. It is presented in Figure 3. This was used in FAO report of 2014 (RM-TWG), and other scientific paper: Bullock (et al. 2017) reported that food quantity, expressed as the amount of production or food calories, is the most common metric of food security and thus resilience.

Figure 2. Land under cultivation, technical endowments and livestock in Romania, 1990-2018

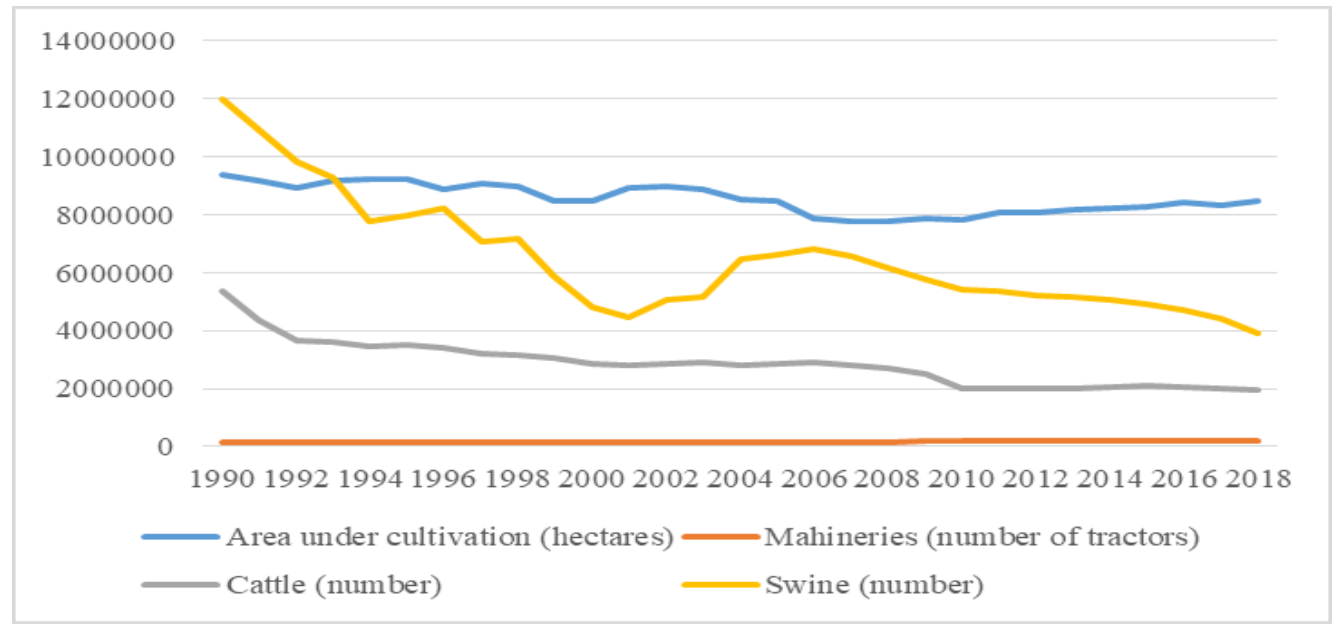

Source: National Institute of Statistic of Romania 
Figure 3. Food supply in Romania, 1990-2018 (kcal/capita/day)

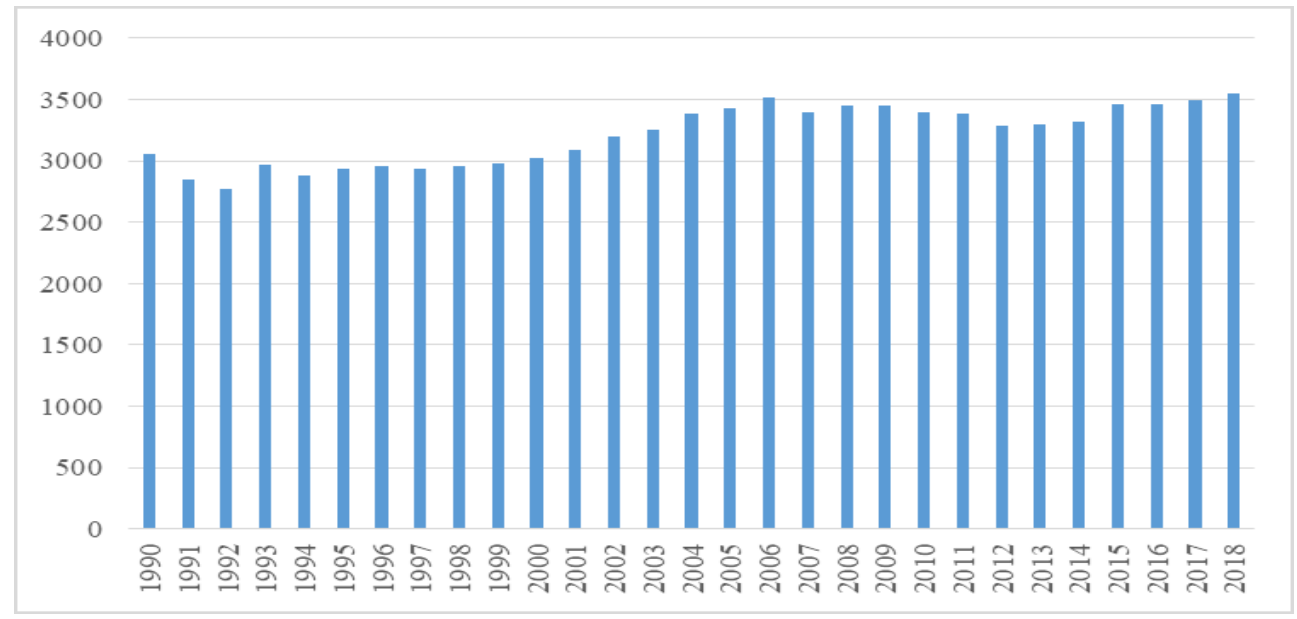

Source: National Institute of Statistic of Romania

As seen in Figure 2, the land under cultivation dropped by 1 million hectares within the period 1990-2018, from 9,402,113 hectares to 8,466,658 hectares. The number of agricultural tractors almost doubled within the period under analysis, from 127,065 to 215,980 . The livestock dramatically decreased, almost three times, for both cattle and swine, from 5,380,780 to $1,977,232$ in the case of cattle, and from 12,003,384 to $3,925,283$, in the case of swine. This situation is explained by the structural changes registered in Romanian agriculture after 1989, when large agricultural exploitations belonging to the state or cooperative systems have been divided into smaller private farms. The same situation experienced the livestock, when larger state or cooperative exploitations have been closed or privatized.

Figure 3 reveals an oscillatory trend for food supply, with an overall increasing trend from $3053 \mathrm{kcal} /$ capita/day to $3552 \mathrm{kcal} /$ capita/day, in the period under analysis. It can be noticed that the values of food supply, expressed in calories per person per day, are higher than recommendations and closed to the average world consumption of almost $3000 \mathrm{kcal} / \mathrm{capita} /$ day. We can assert that food security is ensured, on average, in Romania, as statistical indicators show and the results of other scientific papers (Istudor et al.2014).

\section{Results}

For assessing the influence of agricultural assets on farmers' resilience, the relationship between food security, as dependent variable, and resilience capacity are analyzed.

The indicators are introduced into SPSS and analyzed using simple regression model, using 28 observations. The results of the model of regression are presented in Table 2, showing the influence of the agricultural assets, land, machinery, cattle and swine, on food supply. 
Table 2. The influence of agricultural assets on food supply

\begin{tabular}{|l|c|c|c|}
\hline Variable & $\begin{array}{c}\text { Coefficients of } \\
\text { correlation }\end{array}$ & Standard error & Sig. \\
\hline Land & 0.616 & 0.000 & 0.000 \\
\hline Machinery & 0.588 & 0.001 & 0.000 \\
\hline Cattle & 0.504 & 0.000 & 0.000 \\
\hline Swine & 0.412 & 0.000 & 0.000 \\
\hline
\end{tabular}

Source: Author's calculations

The agricultural assets have moderate influence on food supply, because the values of the coefficients of correlation are around 0.5 . The land registered the highest influence of agricultural assets on food supply, since the value of the coefficient of correlation is 0.616 , compared to machinery (0.588), cattle (0.504) and swine $(0.412)$. The results of the regression model are retrieved with a standard error bellow 0.001 and a probability of $95 \%$.

The analysis goes deep into the macro regions of Romania, assuming that the influence of agricultural assets varies from one region to another, due to their differences in those regarding economic activity, agricultural land, technical endowment, livestock, people income and, generally, people wellbeing. As mentioned before, there are four macro regions in Romania: macro region 1, including North-West and Center, macro region 2, including North-East, South-East, macro region 3, including South-Muntenia, Bucharest-Ilfov, and macro region 4, including South-West Oltenia and West. The influence of the agricultural assets on food supply is presented in Table 3.

It can be noticed that significant results are registered for macro region 4, West and South-West Oltenia, where land use and machinery influence food supply, since the values of the coefficients of correlation between variables are above 0.5 . They show a medium correlation between variables. The relations are negative, as the values of the coefficients of the regression function show. The results are retrieved with standard errors bellow 0.005 , and a probability of $95 \%$.

Table 3. The influence of agricultural assets on food supply, by region

\begin{tabular}{|c|c|c|c|c|}
\hline Variable & $\begin{array}{c}\text { Coefficients of } \\
\text { correlation }\end{array}$ & $\begin{array}{l}\text { Coefficients of the } \\
\text { regression function }\end{array}$ & $\begin{array}{l}\text { Standard } \\
\text { error }\end{array}$ & Sig. \\
\hline \multicolumn{5}{|c|}{ Macro Region 1} \\
\hline Land & \multicolumn{4}{|c|}{$*$} \\
\hline Machinery & \multicolumn{4}{|c|}{ * } \\
\hline Cattle & 0.645 & 0.803 & 0.000 & 0.003 \\
\hline Swine & \multicolumn{4}{|c|}{ * } \\
\hline \multicolumn{5}{|c|}{ Macro Region 2} \\
\hline Land & \multicolumn{4}{|c|}{ * } \\
\hline Machinery & \multicolumn{4}{|c|}{$*$} \\
\hline Cattle & 0.180 & 0.425 & 0.000 & \\
\hline Swine & \multicolumn{4}{|c|}{ * } \\
\hline
\end{tabular}




\begin{tabular}{|c|c|c|c|c|}
\hline Variable & $\begin{array}{c}\text { Coefficients of } \\
\text { correlation }\end{array}$ & $\begin{array}{l}\text { Coefficients of the } \\
\text { regression function }\end{array}$ & $\begin{array}{c}\begin{array}{c}\text { Standard } \\
\text { error }\end{array} \\
\end{array}$ & Sig. \\
\hline \multicolumn{5}{|c|}{ Macro Region 3} \\
\hline Land & \multicolumn{4}{|c|}{$*$} \\
\hline Machinery & \multicolumn{4}{|c|}{$*$} \\
\hline Cattle & 0.487 & 0.698 & 0.000 & 0.170 \\
\hline Swine & \multicolumn{4}{|c|}{$*$} \\
\hline \multicolumn{5}{|c|}{ Macro Region 4} \\
\hline Land & 0.607 & -0.779 & 0.000 & 0.005 \\
\hline Machinery & 0.562 & -0.750 & 0.005 & 0.008 \\
\hline Cattle & \multicolumn{4}{|c|}{$*$} \\
\hline Swine & 0.357 & 0.597 & 0.000 & 0.052 \\
\hline
\end{tabular}

*statistically insignificant

Source: Results of the regression model

In all the other regions, the results of the regression model are significant only for livestock, namely for cattle. In macro region 1, the cattle influence the food supply with a moderate intensity of $64 \%$. The food supply modifies by $0.803 \mathrm{kcal}$ as a result one-unit change in the number of cattle. In macro region 2 , the cattle influence the food supply with a low intensity of $18 \%$. The food supply modifies by $0.425 \mathrm{kcal}$ as a result one-unit change in the number of cattle. In macro region 3 , the cattle influence the food supply with a moderate intensity of $48 \%$. The food supply modifies by $0.698 \mathrm{kcal}$ as a result one-unit change in the number of cattle.

For land and machinery, although they are significant agricultural assets in farms activities, the results are not statistically significant. This could be considered a limit of the research, needing a detailed analysis, using different econometric methods and models.

Figure 4. The histograms showing the relationships between cattle and food supply in macro region 1 (a), macro region 2 (b) and macro region 3 (c)

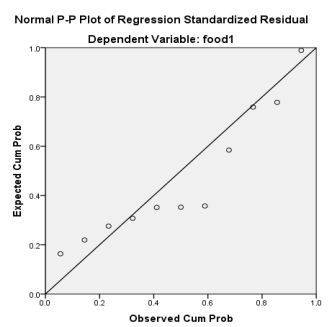

(a)

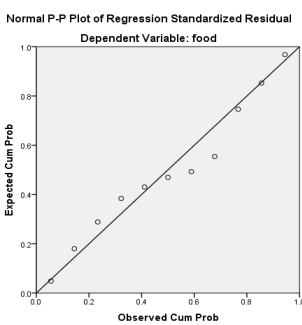

(b)

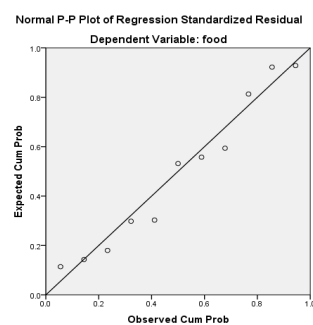

(c)

Source: Results of the regression model 


\section{Conclusions}

The results of the research validate the hypothesis, assumed at the beginning of the article, that the level of assets plays a role in assessing the risk level of farmer's exposure to shocks and stressors and causes the level of individuals' and farmers' food supply. The results of the regression models show medium influences of the agricultural assets on food supply and regional disparities concerning the relationships of the agricultural assets on farmers' resilience. Thus, significant influences have registered in macro region 4, West and South-West, for land, machineries and swine. Less significant influences have registered in all the other macro regions, where only cattle influence, with a lower intensity, the food supply.

\section{Acknowledgements}

This work was supported by a grant of the Ministry of Research and Innovation, CNCS - UEFISCDI, project number PN-III-P4-ID-PCCF-2016-0166, within the PNCDI III project "ReGrowEU - Advancing ground-breaking research in regional growth and development theories, through a resilience approach: towards a convergent, balanced and sustainable European Union".

\section{Conflict of interests}

The authors declare no conflict of interest.

\section{References}

1. Apostolache, M. (2014). Regional Development in Romania - From Regulations to Practice. Procedia Economics and Finance, 8, 35-41. https://doi.org/10.1016/ S2212-5671(14)00059-8

2. Berkes, F., \& Turner, N.J. (2006). Knowledge, learning and the evolution of conservation practice for social-ecological system resilience. Human Ecology, 34(4), 479-494. https://doi.org/10.1007/s10745-006-9008-2

3. Bullock, J.M., Dhanjal-Adams, K.L., Milne, A., Oliver, T.H., Lindsay, T.C., Whitmore, A.P., \& Richard, P.F. (2017). Resilience and food security: rethinking an ecological concept. Journal of Ecology, 105(4), 880-884. https:/doi. org/10.1111/1365-2745.12791

4. Burešova, P., Mrkvova, K., \& Dudić, B. (2020). Changes in gastronomy. Hotel and Tourism Management, 8(1), 79-88. https://doi.org/10.5937/menhottur2001079B

5. Ellis, F. (2000). Rural Livelihoods and Diversity in Developing Countries. Oxford University Press, Oxford, UK.

6. European Commission. (2020). Boosting EU regions' health and well-being. Panorama. Focusing on European Regional and Urban Policy, 73, 16-17. 
7. Food and Agriculture Organization of the United Nations (FAO), (2016). Complete Analysing Resilience for better targeting and action. Resilience Index Measurement and Analysis - II, Rome: FAO. Retrieved from: http://www.fao. org/3/a-i5665e.pdf (13 November, 2020).

8. Gunderson, L.H., \& Holling, C.S. (2002). Panarchy. Understanding Transformations in Human and Natural Systems, Island Press, Washington DC, USA.

9. Hoffmann, V., Probst K., \& Christinck, A. (2007). Farmers and researchers: how can collaborative advantages be created in participatory research and technology development? Agriculture and Human Values, 24(3), 355-368. https://doi. org/10.1007/s10460-007-9072-2

10. Holling, C.S. (1973). Resilience and stability of ecological systems. Annual Review of Ecology and Systematics, 4, 2-23.

11. Istudor, N. (2006). Regional and rural development of Romania in the perspective of EU integration, Bucharest: ASE.

12. Istudor, N., Ion, R.A., Sponte, M., Petrescu, I.E. (2014). Food Security in Romania-A Modern Approach for Developing Sustainable Agriculture. Sustainability, 6(12), 8796-8807, doi: 10.3390/su6128796.

13. Jokić, M. (2020). The importance of considering internal audit as a decision-making by top-management of an agricultural company. Oditor-časopis za menadžment, finansije i pravo, 6(3), 123-136. https://doi.org/10.5937/Oditor2003123J

14. Law no.315/2004 on regional development. Romania's Official Gazette, no. 577 of June 29, 2004, amended by EGO. no.111/2004 (published in Romania's Official Gazette, no.1115 of November, 27, 2004, approved by Law no.58/2005, published in Romania's Official Gazette, no.257 of March 28, 2005).

15. Milestad, R., \& Darnhofer, I. (2003). Building farm resilience: The prospects and challenges of organic farming. Journal of Sustainable Agriculture, 22(3), 81-97. https://doi.org/10.1300/J064v22n0309

16. Milestad, R., Kummer, S., \& Vogl, C. (2009). Building farm resilience through farmers' experimentation, WS 1.8 - Knowledge systems, innovations and social learning in organic farming, 9th European IFSA Symposium, 4-7 July 2009, Vienna (Austria).

17. Pretty, J. (1998). The living land: agriculture, food and community regeneration in rural Europe. Earthscan, London, UK.

18. Pretty, J. (2002). Agri-culture. Reconnecting People, Land and Nature, Earthscan Publications, London, UK.

19. RM-TWG(Resilience Measurement Technical Working Group), (2014). Resilience Measurement Principles - Toward an Agenda for Measurement Design, 1, 2014. 
20. Röling, N., \& Jiggins, J. (1998). The ecological knowledge system. In: Röling, N. and Wagemakers, W.A.E, Facilitating sustainable agriculture: participatory learning and adaptive management in times of environmental uncertainty. Cambridge University Press, Cambridge, 283-307.

21. Scoones, I., \& Thompson, J. (1994). Beyond Farmer First. Rural people's knowledge, agricultural research and extension practice, Intermediate Technology Publications, London, UK.

22. Stanković, V., Mrdak, G., \& Miljković, M. (2020). Economic-legal analysis of international investments. Oditor-časopis za menadžment, finansije i pravo, 6(3), 89-122. https://doi.org/10.5937/Oditor2003089S

23. Stankevičiūtè, Ž., \& Wereda, W. (2020). Universalism values and organisational citizenship behaviour referring to employee perception of corporate social responsibility. Management \& Marketing. Challenges for the Knowledge Society, 15(2), 302-325. https://doi: 10.2478/mmcks-2020-0018.

24. Sumberg, J., \& Okali, C. (1997). Farmers' experiments-Creating local knowledge, Lynne Rienner Publishers, London, UK. 